\title{
SERVICE QUALITY OF LIBRARY TOWARD AN INTERNATIONAL COLLEGE QUALITY
}

\author{
RORIM PANDAY \\ Pakuan University, Bogor, Indonesia,Indripan@yahoo.co.id
}

\begin{abstract}
Library has a very important role in the learning process, both for primary, secondary and higher education level. So the main function of the library is to serve students and educators or users of outside education in finding a reference to a sub-field of science or science they are studying. For that, a library that can serve, have references required by the user, can read books and learn in library room. The comfort room and amenities will be a good service value. Library staff who serve also reinforce a good service system. Elibrary services connected with a variety of e-library of agencies in the country and abroad will be an added value to the quality of library services. This study aims to determine how the quality of service of a library. Data taken using a questionnaire developed from the SERVQUAL, where the number of respondents as many as 125 people. Analysis of the data by using the pair-test and factor analysis. From the analysis, showed Tangible components of quality of service already exceeded expectations, while for components Reliability, Responsiveness, Assurance and Empathy, the service quality value is still below the expected value.
\end{abstract}

Keyword: service quality, expected value, perceived value, SERVQUAL

\section{RESEARCH BACKGROUND}

Library has a very important role in supporting teaching learning in higher education. The presence of a library, so students and faculty can gain more knowledge and find the solutions to the problem being studied and trend so remerging. Completeness of books, such as reference books, thesis, dissertation, both in scientific magazines and in digital format will be very supportive for students and faculty in understanding the science or apart of science. For that, a good library, it is fitting to have a data base systems and computer networks associated with the library network in the world, or with other universities, both 
domestically and abroad. With the Library, the university will be rich with its management content. University that have a management content are many and varied, will encourage the universities become the famous universities in the world.The library of Christian University of Indonesian is one of the libraries that are already equipped with an e-library and connected with library in the world in the Internet network system.

Library of Christian University of Indonesia established since the end of 1986, beginning of the fore runner of the current economic faculty library was only 3 employees, with the motto "Serving Not Served" until now, the Indonesian Christian University library serves the academic community on two (2) location, i.e: Cawang and college campuses Diponegoro 84-86, Central Jakarta. On the web page there is a Lecturer Publications, Online Catalog, Mail Live @ edu, as well as various Electronic Journal: ProQuest, EBSCO, Portal Garuda Cengange and built in cooperation between the Directorate General of Higher Education and Scientific Information and Documentation Centre (WWII-LIPI) and various contributors.

Currently the Christian University of Indonesian has7 faculties, of which 6 (six) is in the Campus Faculty Cawang, and 1(one) is in the Campus Faculty Diponegoro. In 2011 CUI library services that used to change the system using Closed System (Close Access) is now the Open Systems (Open Access), which is now the student can immediately pick up and read a book shelf or directly into the collection chamber. Libraries on Campus Cawang located on the first floor building B, the total area of the building/room: 1,982m2. Libraries on Campus Jl. Diponegoro total area of the building/room: $376 \mathrm{~m} 2$. The plan in the time soon will begin immediately centralization of medical school libraries, but all activities are under the administrative center library fetched as well as the law school library at Jalan Diponegoro, Central Jakarta. Of the various types of activities the college library that should be provided, only part of it that can be implemented by the central library CUI, namely:

1. Procurement activities of library materials.

2. Service Activity (circulation).

3. General Reference Service Activity.

4. Event Information Services selected 
Procurement is collection through purchase are the most important ways to be more profitable and because we determine which collection we want, it is different if the collection is obtained by way of a grant/gift. The purpose of procurement of library materials is to meet the needs of service users, in other words the procurement of the library collection is in tended to continue to present the latest information for its users.

Services were held at the central library CUI cover circulation services, service reading room reference and selected information services. Borrowers allowed to choose their own desired books on a bookshelf.

The purpose of the library service is effort that done by the library to serve the users with the intent to meet the needs of the user. Therefore it can be said the quality of a library will be reflected in terms of services provided to the user.

Beside service to be brought the home, the library also serves read in places/services the reference. In essence this is the reference service activity to find the information, and answer the questions by using the reference collection as well as provide guidance to find and use the reference collection.

To carry out the work properly, it is necessary adequate the reference collection, the capable officer in collaboration between the other college library by way of catalog exchange.

The reference collection includes:

1. Almanac and yearbook

2. Handbooks and magazines

3.Directory

4. Encyclopedia

5. Dictionary

The objectice Reference is to provide assistance to the users of reference service both students, lecturers and researchers. To search for, collect, assess and use library materials in the learning activities, teaching instructional and research.

CUI library in the reference services it can be said to implement semi open. Which meant a semi-open is in providing some services the reference books in the reading room, a bookshelf, which can be used without having to ask the concierge service at the reference, while the thesis must be a serving by officer. 
Type collections of the reference room are:

1.The reference-books

2.Thesis

\section{Magazine}

\section{Newspaper}

Selected Information services is aimed to teachers/lecturers of CUI, by sending a copy the content of the scientific magazine related to each department.

Although the thesis including the reference books, but require special work means that can not be copied like other the reference books. Thesis can only be read on the spot. How to lending, it is the same way with borrowing the textbooks. In searching title/subject can be seen through the arrangement of the card catalog, specially with thesis that was in the circulating room with the alphabetical arrangement. As for how lending the thesis can be seen in the libraries rule and also other borrowing.

Various CIU library facilities given to the visitors, so that provide more comfort for visitors to acquire knowledge.

The library facilities provided are:

1. Collection Room and Reading Room

2. Space Discussion

This room can be used by students to work on assignments in groups of Hot Spot:

a. Internet Facilities based Wireless Fidelity (WiFi) which can be accessed on the device and the communication of mobile phones, PDAs, notebooks to obtain this facility by contact theBureau of Information Technology.

b. To a visitor of CUI valid for 1or 2 hours with a password provided by the Library in cooperation with the Bureau of Information Technology.

3. Library collection :

Books : a. Non Fiction : 17.000 Titles 33.275 copies

b. References : 384 Titles 583 Copies

c. Fictions $\quad: 541$ Titles

Magazine :

- Journal $\quad: \quad 7$ Titles

- News paper : 4 Titles 


$\begin{array}{lll}\text { - Bachelor thesis } & : & 1473 \text { Titles } \\ \text { - Thesis } & : & 300 \text { Titles } \\ \text { - Dissertation } & : & 78 \text { Titles } \\ \text { - Multimedia } & : & 74 \text { Titles }\end{array}$

Given the condition of the library, it will be to know how the service quality of the library to date. Various studies have been conducted about libraries, both in the country and who is outside the country. This study will use the principle of SERVQUAL.

SERVQUAL is the most popular instrument to ascertain service quality. However, some debate exists about its ability to characterize different service environments. Furthermore, there is not a consensus about the inclusion of customer expectations in the model.SERVQUAL was originated in 1988 and it was founded on the conceptual model developed by Parasuraman et al.(1985). The early work of these researchers was based on the comparison of service performance against a single expectation standard. According to this, perceived service quality can be expressed as follows:

Perceived service quality $=$ perceived service $(P)-$ expected service $(E)$

SERVQUAL instrument (Parasuraman et al., 1988) is used to assess customer's expectations and perceptions. The instrument includes five dimensions of service quality: tangibles, Reliability, Responsiveness, Assurance and Empathy. (Zeithaml et al, 1990). Many research about service quality used the SERVQUAl at many type of services have been done. Generally, the papers, many of which are already using the concept of SERVQUAL to know the quality of their services provided associated with the level of satisfaction of these services.

Relation to customer satisfaction, and quality of service has done the research on the railways, there are some researchers who have conducted research on the matter.Sheeba. A and K. Kumuthadevi (2013), research do on passenger (Customer) satisfaction of Indian railways and service quality. Syed Muhammad Irfan, Daisy Mui Hung Kee and Saman Shahbaz (2012) do research of service quality and rail transportation in Pakistan. They research aims to investigate the passengers' perceptions about the service quality of rail transport system in Pakistan. A modified SERVQUAL instrument including eight service quality constructs: empathy, assurance, tangibles, timeliness, responsiveness, information 
system, food and safety and security were employed to measure the passengers" perceptions about the service quality of railways.

Khan Rubayet RAHAMAN and Md. Arifur RAHAMAN (2009), do research of service quality attributes affecting the satisfaction on railway passenger at selective route in southwestrn part of Bangladesh.

Abadi dwi Saputra (2010)do his research in Indonesia on analysis of train passenger responses on provided service. The objective of his research is to analyze the relationship between customer satisfaction towards provided service with the desire to do a complaint and to find the factor from service quality that has significant influences to customer satisfaction towards PT KAI services.

Panday Rorim (2013) has done his research on service quality and passenger satisfaction on Argo Parahyangan train bandung jakarta route.

Implemented SERVQUAL for service quality research aslo done by Vera Patrico(2006). He implemented the SERVQUAL in restaurat in a Portuguese Resort.

Particular for this research paper, in Indonesia has been done the research of library related to service quality of library or quality of library, used by many methods and variables that designed regarding by researcher. They use descriptive analysis, qualitative and quantitative methods. Siti Musthofainah (2009) in her research Student Perception on Facilities of The Library of Public State Vacational School 1 Bantul Yogyakarta. Her researh objectives is to know the student perception about the facilities of the library of public state vacational school 1 Bantul Yogyakarta. Number of respondent as 92 students.To achieve of data collection by: observation, documentation, interview, questionnaires, and library study. The result of her researchesis that the library facility has reached $85,9 \%$ as good and 14,1 as very good. Building of the school categorized as good $(78,2 \%)$, very good $(10,9 \%)$ and bad(10,9\%). Library room catagorized as Good $(84,7 \%)$, Bad ( $12 \%)$ and very good (3,3\%). Beside, perception on completeness facility and quality aspect can be categorized can be categorized as $\operatorname{good}(85,9 \%)$ and bad $(14,1 \%)$. Concluded, that most respondent perceived the building, the room and the completeness of library as good category. ArifulMiftakhuddin (2012) in his research title as " Relations Student perception of Quality and use of the library services library by Class XI and XII area of power Expertise power Plant Engineering SMKN 2 Yogyakarta.This study aims to 
determine: 1) the relationship between students' perceptions about the quality of the library and library use by students, 2) the relationship between students' perceptions about library services and library use by students, 3 ) the relationship of students' perceptions aboutthe quality of the library and library services with the use of the library by students. This research is a kind of ex post facto research. Data collection technique using a questionnaire. As respondents are the student of XI and XII class of Power Installation Engineering Department SMK Negeri 2Yogyakarta as 71respondents from248students. The data analysis technique used is a simple regression analysis techniques and multiple regression analysis to analyze the hypotheses. The research result of hypothesess how that positive relation between dependent variable and independent variables.

In the two study in Indonesian libraries above not apply SERVQUAL. If we look at both these studies examined only one part or several parts of the SERVQUAL. In the study by Siti Musthofainah only deals with Tangibles factor alone, and then only partially tangibles that exist in the library.

Sunani (2012), her research study aims to investigate the quality of service of Politeknik Sriwijaya University (tangible, reliability, responsiveness, assurance, and empathy) simultaneously affect student satisfaction. Furthermore, if the quality of library service each (tangible), (reliability), (responsiveness), assurance), (empathy) effect partially on student satisfaction in getting learning resources. Her research method is done with the initial survey, preparing instruments, test validity and reliability. Furthermore, multiple regression analysis). Hypothesis Testing with Inferential Statistical Analysis of Multiple Correlation test performed (R), Test coefficient of determination (R2), $\mathrm{F}$ test, $\mathrm{t}$ test using SPSS (Statitical Program for Social Sciences) version 19.0. From the analysis carried out can be concluded that there is an influence of service quality of Politeknik Sriwijaya University (tangible, reliability, responsiveness, assurance, and empathy) simultaneously for student satisfaction in getting learning resources. Furthermore, it turns out the four variables X ((tangible, (reliability ), (responsiveness, assurance) each had no effect partially, whereas empathy variable is the one variable that affects the quality of service.

Narit Nimsomboon and Haruki Nagata (2003), Their study examines the overall service quality of Thammasat UniversityLibrary System from users' perspectives, as well as identifies the dimensions that determine the customers' evaluation of service quality The 
concept of the Zone of Tolerance was applied to investigate which are the essential attributes that library managers should allocate the resource for good service quality. The problems users had encountered when involved in library service are also investigated in this study. A survey of undergraduate students, graduate students, facutly members and researchers was used. The modification of SERVQUAL questionnaires were distributed for data gathering. Several insight gained from this study shown that all users desired expectations are not met. The result of the Zone of Tolerance reveals that each user group was treated differently. The three dimensions of service quality ; Affect of service Organizational, Collection \& Access, and Affect of service - Personal were extracted byf actor analysis method. The problems users encountered when involved in library service are counted manually and categorized into free categories. The most problematic is about insufficient and non update collection. Some useful recommendations are presented to improve service quality of TU library system.

Julia C. Blixrud (1999), and with her team to make tool evaluation on library called as LibQUAL and applied in USA Library. The tools is developement of SERQUAL that introduced by Parasuraman et al.

Shafiq Ur Rehman (2012), applied LibQUAL in his study investigates the perceived service quality of public and private sector university libraries of Pakistan from its users' perspective. More precisely the study compares the following four aspects between public and private universities: zone of tolerance for overall and individual user groups, dimension wise zone of tolerance for overall and individual user group, gaps between desires and perceptions, and significant differences in the service quality. The data were collected through LIBQUAL print questionnaire from 1473 library users (faculty, graduates and undergraduates) of 22 public and private sector university libraries (main/central) of Pakistan. The psychometric properties of instrument were established through exploratory and confirmatory factor analyses. The comparisons of overall, individual service level, and dimension wise gap scores revealed that private sector university libraries were generally meeting the minimum requirements of their users (except information control dimension) but, on the other hand, public sector libraries were not meeting minimum requirement in information control and affect of service dimensions. The study also found significant difference on service quality between private and public sector university 
libraries. The researcher found very interesting findings that small collection creates small expectations, and it is easy to meet or satisfy the needs of the users of small collection. The article also discusses findings, implications of results and limitations of the study at the end.

Ibrahim Danjuma, and Amran Rasli (2012), their study, explored both expectations and perceptions of students on the service quality of the central academic library in a Nigerian technological university. Data for this study was collected by means of qualitative interview. Fifty final year undergraduate students organised into 10 focus groups of 6 each, drawn from faculties of engineering, management and science participated in the focus group discussion. This study reveals five factors: technology, facilities, currency of collections and materials, environment and professionalism as relevant in explaining both expectations and perceptions of students with regards to service quality dimensions of academic libraries in technological universities. Managerial implications, limitations and suggestions for further research were presented accordingly.

Fahimeh Babalhavaeji, Alireza Isfandyari-Moghaddam,Seyed Vahid Aqili, and Ali Shakooii, presented their research aims to assess the performanceof libraries at the Islamic Azad University, Sciences and Research Branch (IAUSRB) through gap analysis. To do this, a researcher-developed questionnaire which is based on available standardsand quality assessment tools including ACRL standards, LibQUAL and ISO 11620, and some criteriaincluded in the related literature was designed and distributed among users of IAUSRB libraries. Five service quality categories, were included in the questionnaire: "Environment, equipment and physical facilities", "Public services", "Non-book materials", "Staff (librarians and their co-workers)", and "Information literacy and user education". Based on research findings, the most expected library services prioritized by users are"operation time" (mean $=4.2300)$, "staff" (mean $=4.1461)$, and "circulation" (mean = 4.1208), while the least expected library services which areof lower importance from users' perspective are "press" (mean $=3.9734)$ and "audiovisual materials" (mean $=3.8796)$. The findings also indicate that services offered by the libraries surveyed had a relatively quality performance and average success (perceived quality is $2.9635 \approx 50 \%$ ). In other words, such a finding emphasizes an average performance of IAUSRB libraries. In addition, confirming five research hypotheses concerning gap analysis, there was a significant difference 
between expected quality of five service categories and their perceived quality based on users' viewpoint. It was also realized that the categories with better performance or perceivedquality from users' perspective are "staff" (mean = 3.2240), "information literacy and user education" (mean $=2.9998)$, and "environment, equipment and physical facilities" $($ mean $=2.9871)$, and the two libraries "Theology and Philosophy" $($ mean $=2.2639)$ and "Medical Engineering" (mean $=2.4507$ ) have offered poor services than the other IAUSRB libraries. So, in their research, they use a simple statistics, mean and t-test statistics.

Based on review literature research above, there are many way how the researchers investigate about the service quality on library, in the school library, university library, private and public library. Some of them used SERVQUAL, and some of another use LibQUAL, and some of researchers use freely instrument that they make based on the condition and invorement of the object of library. In this paper, the research based on the SERVQUAL principle that has been modified.

\section{RESEARCH METHODS}

This study uses the concept of SERVQUAL that has modified, adapted with theCUIlibrary. SERVQUALismodifiedas follows:

\section{Tangibles}

1. Library has modern-looking equipment

2. The physical facilities are visually appealing

3. Library Employees are neat-appearing

4. Materials associated with the service are visually appealing

5. Library equippedwith acomputerized data basesystem

6. Library equipped with airconditiong system

7. Pleasant reading room

8. Library is equipped with e-library

\section{Reliability}

9. When the library promises to do something by a certain time, it does so

10 . When a visitor has a problem, the library shows a sincere interest in solving it 
11. The library performs the service right the first time

12. Services are provided at the time the library promises to do

13. The records are error-free

\section{Responsiveness}

14. Employees tell visitors when services will be performed

15. Employees give prompt service to visitors

16. Employees are willing to help visitors

17. Employees are never too busy torespond to visitor's requests

\section{Assurance}

18. The behaviour of employees instil confidence in visitors

19. Visitors feel safe in library and convenience

20. Employees are consistently courteous

21. Employees have the knowledge to answer visitor's questions

\section{Empathy}

22. Library gives individual attention to the visitor

23. Employees give personal attention to visitors

24. Library understands specifics needs of its visitors

25. Library has visitor's interest at heart

26. Operating hours are convenient to all visitors

This study used a questionnaire, where is intended to determine the expectations value of library by visitors and library service quality with regard to the items being assessed. Assessmentofthe value ofservice expectations:

$1=$ Strongly disagree

$2=$ disagree

3=Agree

4=Strongly agree

$5=$ Strongly agreecompletely

Assessment of quality of service are: 


$$
\begin{aligned}
& 1=\text { worst } \\
& 2=\text { Bad } \\
& 3=\text { Moderate } \\
& 4=\text { Good } \\
& 5=\text { Very well }
\end{aligned}
$$

As the respondents in this study were visitors to the library, which is likely to be composed of students, faculty staff and the public.Thus, there area total of 125 respondents planned. Data processed using SPSS version 11.5, under windows program. Data processed by factor analysis and pair t-test. Description analysis will be done also.

\section{RESULT AND DISCUSSIONS}

From the data collected, tested the validity and reliability. This test aims to determine whether the data obtained from the questionnaire, the level of validity and reliability can be trusted and relied on. Using the Pearson Correlation for test validity and reliability testing

\begin{tabular}{|c|c|c|c|c|c|c|c|c|c|}
\hline & $\begin{array}{l}\text { Pearson } \\
\text { correlation }\end{array}$ & & $\begin{array}{c}\text { Pearson } \\
\text { correlation }\end{array}$ & & $\begin{array}{c}\text { Pearson } \\
\text { correlation }\end{array}$ & & $\begin{array}{l}\text { Pearson } \\
\text { correlation }\end{array}$ & & $\begin{array}{c}\text { Pearson } \\
\text { correlation }\end{array}$ \\
\hline E1 &, $471(* *)$ & E9 &, $636\left(^{* *}\right)$ & E14 &, $618\left(^{* *}\right)$ & E18 &, $747\left(^{* \star}\right)$ & E22 &, $704\left({ }^{* *}\right)$ \\
\hline E2 &, $578(* *)$ & E10 &, $702\left({ }^{* *}\right)$ & E15 &, $671\left({ }^{* *}\right)$ & E19 &, $766\left({ }^{* *}\right)$ & E23 &, $739\left(^{* *}\right)$ \\
\hline E3 &, $538(* *)$ & E11 &, $773\left({ }^{* *}\right)$ & E16 &, $803\left({ }^{* *}\right)$ & E20 &, $833\left({ }^{* *}\right)$ & E24 &, $754\left({ }^{* *}\right)$ \\
\hline $\mathrm{E} 4$ &, $526(* *)$ & E12 &, $752\left({ }^{* *}\right)$ & E17 &, $754\left({ }^{* *}\right)$ & E21 &, $715\left({ }^{* *}\right)$ & E25 &, $730\left(^{* *}\right)$ \\
\hline E5 &, $487(* *)$ & E13 &, $747\left(^{* *}\right)$ & & & & & & \\
\hline E6 &, $556(* *)$ & & & & & & & & \\
\hline E7 &, $649(* *)$ & & & & & & & & \\
\hline E8 &, $648(* *)$ & & & & & & & & \\
\hline & & \multicolumn{6}{|c|}{ RE L I A B I L I T Y A N A L Y S IS - S C A L E (A L P H A) } & & \\
\hline \multicolumn{2}{|c|}{ Alpha $=, 6719$} & \multicolumn{2}{|c|}{ Alpha $=, 7692$} & \multicolumn{2}{|c|}{ Alpha $=, 6699$} & \multicolumn{2}{|c|}{ Alpha $=, 7646$} & \multicolumn{2}{|c|}{ Alpha $=, 7682$} \\
\hline
\end{tabular}
by calculating Cronbach coefficient. The results of the testing, by using SPSS, can be seen in Table- 1 for the data expectations values and of the table- 2 for the value of quality of service.

Table-1 Validity test and Reliability test for Expected value 
From Table 1, it is seen that the Pearson correlation value for each variable is significant at the 0.01 level. Thus the data obtained from the questionnaires as valid. For Cronbach values for each group questionnaire, where questionnaires grouped in a five component of SERVQUAL, value cronbach also been greater than 0.5 , so it can be said the results of the questionnaire is reliable.

Table-2 Validity test and Reliability test for Service quality

\begin{tabular}{|c|c|c|c|c|c|c|c|c|c|}
\hline & $\begin{array}{c}\text { Pearson } \\
\text { correlation }\end{array}$ & & $\begin{array}{c}\text { Pearson } \\
\text { correlation }\end{array}$ & & $\begin{array}{c}\text { Pearson } \\
\text { correlation }\end{array}$ & & $\begin{array}{l}\text { Pearson } \\
\text { correlation }\end{array}$ & & $\begin{array}{c}\text { Pearson } \\
\text { correlation }\end{array}$ \\
\hline $\mathrm{P} 1$ &, $563\left({ }^{* *}\right)$ & P9 &, $561\left(^{* *}\right)$ & P14 &, $539\left({ }^{* *}\right)$ & P18 &, $699\left(^{* *}\right)$ & P22 &, $703\left(^{* *}\right)$ \\
\hline P2 &, $533\left({ }^{* *}\right)$ & P10 &, $789\left(^{* *}\right)$ & P15 & ,658(**) & P19 &, $783\left({ }^{\star \star}\right)$ & P23 &, $684\left(^{* *}\right)$ \\
\hline P3 &, $465\left(^{* *}\right)$ & P11 &, $765\left({ }^{* *}\right)$ & P16 &, $778\left({ }^{* *}\right)$ & P20 &, $852\left({ }^{* *}\right)$ & P24 &, $774\left(^{* *}\right)$ \\
\hline $\mathrm{P} 4$ &, $630\left({ }^{* *}\right)$ & P12 &, $763\left({ }^{* *}\right)$ & P17 &, $698\left({ }^{* *}\right)$ & P21 &, $773\left({ }^{* *}\right)$ & P25 &, $766\left(^{* *}\right)$ \\
\hline P5 &, $676\left({ }^{* *}\right)$ & P13 &, $702\left({ }^{* *}\right)$ & & & & & P26 &, $687\left(^{* *}\right)$ \\
\hline P6 &, $533\left({ }^{* *}\right)$ & & & & & & & & \\
\hline P7 &, $527\left(^{* *}\right)$ & & & & & & & & \\
\hline P8 &, $487\left(^{* *}\right)$ & & & & & & & & \\
\hline & & \multicolumn{6}{|c|}{ RELIABILITY ANALYSIS - SCALE (ALPHA) } & & \\
\hline \multicolumn{2}{|c|}{ Alpha $=, 6746$} & \multicolumn{2}{|c|}{ Alpha $=, 7594$} & \multicolumn{2}{|c|}{ Alpha $=, 5711$} & \multicolumn{2}{|c|}{ Alpha $=, 7790$} & \multicolumn{2}{|c|}{ Alpha $=, 7699$} \\
\hline & & & $\begin{array}{l}\text { ** Correlatic } \\
* \text { Correlatio }\end{array}$ & $\begin{array}{l}\text { is signif } \\
\text { is signifi }\end{array}$ & $\begin{array}{l}\text { ant at the } 0.0 \\
\text { ant at the } 0.0\end{array}$ & $\begin{array}{l}1 \text { level (2 } \\
5 \text { level (2 }\end{array}$ & $\begin{array}{l}\text {-tailed). } \\
\text {-tailed). }\end{array}$ & & \\
\hline
\end{tabular}

From Table 2, it is seen that the Pearson correlation value for each variable is significant at the 0.01 level. Thus the data obtained from the questionnaires as valid. For Cronbach values for each group questionnaire, where questionnaires grouped in a component 5 SERVQUAL, value cronbach also been greater than 0.5 , so it can be said the results of the questionnaire is reliable.

Having in mind that the data from the questionnaire is valid and reliable, then the data can continue to be analyzed. The first analysis was to test between the average value of each variable on the expected value with the average value of the Perceived value (service quality) using pair t-test. Results count pair t-test can be seen in Table-3. 
Table-3 Mean and t- test result

\begin{tabular}{|c|c|c|c|c|c|c|}
\hline No & Questionnaires Items & E-Mean & P-Mean & & & $\mathrm{t}$ \\
\hline 1 & Library has modern-looking equipment & 4,13 & 4,35 & Pair 1 & $\mathrm{E} 1-\mathrm{P} 1$ & $-4,540$ \\
\hline 2 & $\begin{array}{l}\text { The physical facilities are visually appealing } \\
\text { and convenience }\end{array}$ & 3,94 & 4,27 & Pair 2 & $E 2-P 2$ & $-5,698$ \\
\hline 3 & Library Employees are neat-appearing & 3,89 & 4,14 & Pair 3 & E3-P3 & $-4,428$ \\
\hline 4 & $\begin{array}{l}\text { Materials associated with the service are } \\
\text { visually appealing }\end{array}$ & 3,85 & 4,25 & Pair 4 & $\mathrm{E} 4-\mathrm{P} 4$ & $-6,039$ \\
\hline 5 & $\begin{array}{l}\text { Library equippedwith acomputerized data } \\
\text { basesystem }\end{array}$ & 4,01 & 4,24 & Pair 5 & E5 - P5 & $-4,074$ \\
\hline 6 & Library equipped with airconditiong system & 4,06 & 4,24 & Pair 6 & E6 - P6 & $-3,751$ \\
\hline 7 & Pleasant reading room & 4,11 & 4,23 & Pair 7 & E7 - P7 & $-2,976$ \\
\hline 8 & Library is equipped with e-library & 3,75 & 4,11 & Pair 8 & E8 - P8 & $-6,288$ \\
\hline 9 & $\begin{array}{l}\text { When the library promises to do something } \\
\text { by a certain time, it does so }\end{array}$ & 3,85 & 3,49 & Pair 9 & E9-P9 & 6,416 \\
\hline 10 & $\begin{array}{l}\text { When a visitor has a problem, the library } \\
\text { shows a sincere interest in solving it }\end{array}$ & 3,89 & 3,63 & Pair 10 & $\mathrm{E} 10-\mathrm{P} 10$ & 4,815 \\
\hline 11 & $\begin{array}{l}\text { The library performs the service right the } \\
\text { first time }\end{array}$ & 3,77 & 3,58 & Pair 11 & $\mathrm{E} 11-\mathrm{P} 11$ & 3,778 \\
\hline 12 & $\begin{array}{l}\text { Services are provided at the time the library } \\
\text { promises to do }\end{array}$ & 3,74 & 3,64 & Pair 12 & $\mathrm{E} 12-\mathrm{P} 12$ & 2,500 \\
\hline 13 & The records are error-free & 3,72 & 3,47 & Pair 13 & $\mathrm{E} 13-\mathrm{P} 13$ & 4,804 \\
\hline 14 & $\begin{array}{l}\text { Employees tell visitors when services will } \\
\text { be performed }\end{array}$ & 4,02 & 3,82 & Pair 14 & E14-P14 & 4,281 \\
\hline 15 & Employees give prompt service to visitors & 3,82 & 3,58 & Pair 15 & E15-P15 & 4,692 \\
\hline 16 & Employees are willing to help visitors & 3,97 & 3,79 & Pair 16 & E16-P16 & 3,866 \\
\hline 17 & $\begin{array}{l}\text { Employees are never too busy torespond to } \\
\text { visitor's requests }\end{array}$ & 3,89 & 3,74 & Pair 17 & E17-P17 & 3,705 \\
\hline 18 & $\begin{array}{l}\text { The instill of employees confidence in } \\
\text { visitors }\end{array}$ & 3,92 & 3,70 & Pair 18 & E18-P18 & 4,317 \\
\hline 19 & Visitors feel safe in library and convenience & 3,82 & 3,68 & Pair 19 & E19-P19 & 3,557 \\
\hline 20 & Employees are consistently courteous & 3,84 & 3,60 & Pair 20 & E20 - P20 & 4,678 \\
\hline 21 & $\begin{array}{l}\text { Employees have the knowledge to answer } \\
\text { visitor's questions }\end{array}$ & 3,90 & 3,75 & Pair 21 & E21 - P21 & 3,557 \\
\hline 22 & Library gives individual attention to the & 3,95 & 3,66 & Pair 22 & E22 - P22 & 5,013 \\
\hline
\end{tabular}




\begin{tabular}{|l|l|r|r|r|r|r|}
\hline & visitor & & & & & \\
\hline 23 & Employees give personal attention to visitors & 4,07 & 3,86 & Pair 23 & E23 - P23 & 4,169 \\
\hline 24 & $\begin{array}{l}\text { Library understands specifics needs of its } \\
\text { visitors }\end{array}$ & 4,10 & 3,85 & Pair 24 & E24 - P24 & 4,610 \\
\hline 25 & Library has visitor's interest at heart & 3,95 & 3,74 & Pair 25 & E25 - P25 & 4,065 \\
\hline 26 & Operating hours are convenient to all visitors & 3,96 & 3,67 & Pair 26 & E26 - P26 & 5,090 \\
\hline
\end{tabular}

Based on Table3, it is seen that the average value of the variable X1to X8 of perceived value is greater thant he average value of the expected value of the variable.X1to X8 is the Tangibles value, in that it can be interpreted that the respondents' perceptions of service quality $\mathrm{X} 1$ to $\mathrm{X} 8$ greater than the expectations of respondents to these variables. These results were confirmed by pairt-test values are significant, meaning it is proved that the perceived valueis larger value and different from the value expected value. For variable X8 to X26, the average value of Expected value is greater than the value of perceived value.

These results were confirmed by pairt-test values are significant, meaning it is proved that the perceived value is larger and different value from the expected value. In this case(variable X8toX26) the quality of existing services, has not met expectations(expected) of the respondents. For that we need the improvement of the company to be able to improve and increase the variable $\mathrm{X} 8$ to $\mathrm{X} 26$. How to increase it is to make a priority of variables. In this study, to make the priority, is to process the data expected value and perceived value by using factor analysis.

Perceived value of factor analysis to value, displayed in Table 4, Table-5 and Table-6.The value of Kaiser Meyer Olkin (KMO) as 0.780. The value of Bartlett Test of Sphericity as 1147,891 at the of significant level 0.000 . The value of Anti Image correlation, which are presented in the diagonal value of the matrix are greater than 0,3.Allof that, show that the data of 26 variables are adequate for factor computation.Based on the value of eigenvalue greater than 1 (one) (see table-5), there are 8 group of variables. Each group of variables has different value of variance as shown at table-9.Total variance explained, as 67,816 $\%$,which is indicate that the result of factor computation in satisfactory.For each component, the reduce variable as shown at table- 6 . 
Table-4 KMO and Bartlett's test of service quality

KMO and Bartlett's Test

\begin{tabular}{|c|c|c|}
\hline \multicolumn{2}{|c|}{$\begin{array}{l}\text { Kaiser-Meyer-Olkin Measure of Sampling } \\
\text { Adequacy. }\end{array}$} & 780, \\
\hline $\begin{array}{l}\text { Bartlett's Test of } \\
\text { Sphericity }\end{array}$ & $\begin{array}{l}\text { Approx. Chi-Square } \\
\text { df } \\
\text { Sig. }\end{array}$ & $\begin{array}{r}1247,891 \\
325 \\
, 000\end{array}$ \\
\hline
\end{tabular}

The variance of factor- 1 is $24,871 \%$, the variance of factor- 2 is 9,901 , the variance of factor-3 is 7,355, the variance of factor- 4 is 6,707 , the variance of factor-5 is 5,495 , thre variance of factor- 6 is 4,829 , the variance of factor- 7 is 4,509 and the variance of factor- 8 is 4,150 .

Table-5 Total variance explained of service quality

Total Variance Explained

\begin{tabular}{|c|c|c|c|c|c|c|}
\hline \multirow[b]{2}{*}{ Component } & \multicolumn{3}{|c|}{ Initial Eigenvalues } & \multicolumn{3}{|c|}{ Extraction Sums of Squared Loadings } \\
\hline & Total & $\%$ of Variance & Cumulative $\%$ & Total & $\%$ of Variance & Cumulative $\%$ \\
\hline 1 & 6,466 & 24,871 & 24,871 & 6,468 & 24,871 & 24,871 \\
\hline 2 & 2,574 & 9,901 & 34,772 & 2,574 & 9,901 & 34,772 \\
\hline 3 & 1,912 & 7,355 & 42,128 & 1,912 & 7,355 & 42,128 \\
\hline 4 & 1,744 & 6,707 & 48,834 & 1,744 & 6,707 & 48,834 \\
\hline 5 & 1,429 & 5,495 & 54,329 & 1,429 & 5,495 & 54,329 \\
\hline 6 & 1,256 & 4,829 & 59,158 & 1,256 & 4,829 & 59,158 \\
\hline 7 & 1,172 & 4,509 & 63,686 & 1,172 & 4,509 & 63,686 \\
\hline 8 & 1,079 & 4,150 & 67,816 & 1,079 & 4,150 & 67,816 \\
\hline 9 & .847 & 3,259 & 71,076 & & & \\
\hline 10 & .824 & 3,170 & 74,245 & & & \\
\hline 11 & .748 & 2,877 & 77,122 & & & \\
\hline 12 & .649 & 2,497 & 79,619 & & & \\
\hline 13 & .635 & 2,440 & 82,060 & & & \\
\hline 14 & .562 & 2,163 & 84,223 & & & \\
\hline 15 & .507 & 1,948 & 86,171 & & & \\
\hline 16 & .485 & 1,865 & 88,036 & & & \\
\hline 17 & .462 & 1,778 & 89,814 & & & \\
\hline 18 & ,424 & 1,630 & 91,445 & & & \\
\hline 19 & .403 & 1,551 & 92,995 & & & \\
\hline 20 & .373 & 1,433 & 94,429 & & & \\
\hline 21 & ,330 & 1,288 & 95,697 & & & \\
\hline 22 & 297 & 1,142 & 96,839 & & & \\
\hline 23 & ,242 & .929 & 97,768 & & & \\
\hline 24 & .225 & .864 & 98,633 & & & \\
\hline 25 & , 185 & .713 & 99,345 & & & \\
\hline 28 & .170 & ,655 & 100,000 & & & \\
\hline
\end{tabular}


Referring toTable-6, and the loading factor threshold value for the number of 125 respondents, namely the value of loading factor of 0.50 (Hair. 2000), the 26 variables in the SERVQUAL reduced in eight components. The interpretation of eacxh factor, described in table-7.

Table-6 Rotated compenent matrix of service quality

Rotated Component Matrik

\begin{tabular}{|c|c|c|c|c|c|c|c|c|}
\hline & \multicolumn{8}{|c|}{ Component } \\
\hline & 1 & 2 & 3 & 4 & 5 & 6 & 7 & 8 \\
\hline P1 & .086 &,- 007 &,- 068 & .101 & .698 & .178 & .156 &, 068 \\
\hline $\mathrm{P} 2$ &,- 072 & 208 & .089 &,- 079 & .735 &,- 025 &,- 083 & .239 \\
\hline P3 &, 036 & .000 &,- 030 &,- 076 & 253 &, 012 &, 081 & .829 \\
\hline P4 & .178 &,- 010 & .233 & .411 & .576 &,- 111 &,- 191 &,- 008 \\
\hline P5 &, 235 &, 086 &,- 024 & .709 & 369 &,- 008 &, 025 &,- 079 \\
\hline P6 & .037 & .028 &,- 058 & .790 & .043 &, 017 &, 199 & .036 \\
\hline P7 &, 104 &, 281 &, 128 & .747 &,- 153 &, 191 &,- 128 & 171 \\
\hline P8 & .123 &,- 101 & .066 & , 185 &, 033 &,- 126 &, 047 & .769 \\
\hline P9 &, 308 &,- 089 & .005 & .099 &, 153 & .685 &, 177 &,- 047 \\
\hline P10 & .707 &, 286 &, 074 &, 153 &,- 030 & .200 & .040 &, 110 \\
\hline P11 & .803 & .209 &,- 014 &,- 017 &,- 083 &,- 037 & .016 &, 088 \\
\hline P12 & .799 &,- 033 &, 147 &,- 040 &, 120 &, 067 & .002 &, 039 \\
\hline P13 & .683 & .040 &, 216 &, 182 & .060 &,- 033 &, 051 &,- 096 \\
\hline P14 & .530 &, 123 &,- 090 &, 079 & .037 &, 394 & 260 &, 047 \\
\hline P15 & .250 & .235 & .585 &,- 007 & .234 &,- 116 & 160 & ,146 \\
\hline P16 & .114 & .791 & , 182 & .146 & .122 &,- 031 &, 159 &, 025 \\
\hline P17 & , 185 & .775 &, 105 & .048 &, 003 &, $11 \mathrm{~g}$ &, 060 &,- 181 \\
\hline P18 & , 198 & .796 & , 112 & .053 &, 064 &, 085 & , 130 &, 041 \\
\hline P19 &, 355 &, 368 & , 172 &, 090 &, 012 &,- 063 & .607 & .047 \\
\hline P20 & .297 & .338 & .496 & .067 & .038 &, 058 & .524 &,- 012 \\
\hline P21 & .070 &, 262 &, 368 & .068 &,- 002 &, 170 & .659 & , 190 \\
\hline P22 & .083 & .087 & .856 &,- 025 & .054 &,- 068 &, 070 &,- 025 \\
\hline P23 & .023 &, 374 & .268 &, 028 &, 006 & .715 &,- 054 &,- 128 \\
\hline P24 &, 016 & ,342 & .533 &,- 074 &,- 310 & .424 &,- 220 &,- 060 \\
\hline $\mathrm{P} 25$ & .290 & .309 & .539 &, 187 &,- 037 & 396 &,- 216 &, 013 \\
\hline P26 & .036 & .048 & .634 & .023 &,- 035 & .280 & 338 &,- 014 \\
\hline
\end{tabular}

Extraction Method: Principal Component Analysis.

Rotation Method: Quartimax with Kaiser Normalization.

a. Rotation converged in 9 iterations.

Table-7. Interpretasi factor kualitas pelayanan

\begin{tabular}{|c|l|l|}
\hline Factor & \multicolumn{1}{|c|}{ Variables } & \multicolumn{1}{c|}{ Interpretation } \\
\hline & $\begin{array}{l}\text { P10-When a visitor has a problem, the library shows } \\
\text { a sincere interest in solving it } \\
\text { P11- The library performs the service right the first } \\
\text { time } \\
1\end{array}$ & $\begin{array}{l}\text { These variables in factor-1, have service } \\
\text { quality at the first degree }\end{array}$ \\
& $\begin{array}{l}\text { P13- The records are error-free } \\
\text { P14-Employees tell visitors when services will be } \\
\text { performed }\end{array}$ & \\
\hline
\end{tabular}




\begin{tabular}{|c|c|c|}
\hline 2 & $\begin{array}{l}\text { P16- Employees are willing to help visitors } \\
\text { P17- Employees are never too busy to respond to } \\
\text { visitor's requests } \\
\text { P18- The instill of employees confidence in visitors }\end{array}$ & $\begin{array}{l}\text { These variables in factor- } 2 \text {, have service } \\
\text { quality at the second degree }\end{array}$ \\
\hline 3 & $\begin{array}{l}\text { P15-Employees give prompt service to visitors } \\
\text { P22-Library gives individual attention to the visitor } \\
\text { P24-Library understands specifics needs of its } \\
\quad \text { visitors } \\
\text { P25-Library has visitor's interest at heart } \\
\text { P26-Operating hours are convenient to all visitors }\end{array}$ & $\begin{array}{l}\text { These variables in factor- } 3 \text {, have service } \\
\text { quality at the third degree }\end{array}$ \\
\hline 4 & $\begin{array}{l}\text { P5-Library equippedwith acomputerized data } \\
\text { basesystem } \\
\text { P6-Library equipped with air conditiong system } \\
\text { P7-Pleasant reading room }\end{array}$ & $\begin{array}{l}\text { These variables in factor- } 4 \text {, have service } \\
\text { quality at the fourth degree }\end{array}$ \\
\hline 5 & $\begin{array}{l}\text { P1- Library has modern-looking equipment } \\
\text { P2- The physical facilities are visually appealing and } \\
\text { convenience } \\
\text { P4- Materials associated with the service are visually } \\
\text { appealing }\end{array}$ & $\begin{array}{l}\text { Those variables in factor-5, have service } \\
\text { quality at the fifth degree }\end{array}$ \\
\hline 6 & $\begin{array}{l}\text { P9-When the library promises to do something by a } \\
\text { certain time, it does so } \\
\text { P23-Employees give personal attention to visitors }\end{array}$ & $\begin{array}{l}\text { These variables in factor- } 6 \text {, have service } \\
\text { quality at the sixth degree }\end{array}$ \\
\hline 7 & $\begin{array}{l}\text { P19-Visitors feel safe in library and convenience } \\
\text { P20-Employees are consistently courteous } \\
\text { P21-Employees have the knowledge to answer } \\
\text { visitor's questions }\end{array}$ & $\begin{array}{l}\text { These variables in factor- } 7 \text {, have service } \\
\text { quality at the seventh degree }\end{array}$ \\
\hline 8 & $\begin{array}{l}\text { P3- Library Employees are neat-appearing } \\
\text { P8- Library is equipped with e-library }\end{array}$ & $\begin{array}{l}\text { These variables in factor- } 8 \text {, have service } \\
\text { quality at the eighth degree }\end{array}$ \\
\hline
\end{tabular}

The degree of service quality decrease from first degree to eighth degree, so that, variables which lie at eighth degree (factor-8), are variables with the lowest degree of qualityof service variables compared to another degree. The highest degree of quality of service variable lie in the first degree (factor-1). Based on this, then for improving quality of service for library management should increase and improvement to service quality variables by making priority start from variables in eighth degree in factor- 8 as firts priority, to the last priority are the variables in factor- 1 by considering the result of pair $\mathrm{t}$ test amalysis. The following is a priority strategy to improve service quality variables.

Table-8 Strategy for improvement

\begin{tabular}{|c|l|l|}
\hline Factor & \multicolumn{1}{|c|}{ Variables } & \multicolumn{1}{c|}{ Strategy for improvement } \\
\hline 8 & $\begin{array}{l}\text { P3- Library Employees are neat-appearing } \\
\text { P8- Library is equipped with e-library }\end{array}$ & $\begin{array}{l}\text { These variables has already good service } \\
\text { quality, based on t-test analysis }\end{array}$ \\
\hline 7 & $\begin{array}{l}\text { P19- Visitors feel safe in library and convenience } \\
\text { P20- Employees are consistently courteous } \\
\text { P21-Employees have the knowledge to answer }\end{array}$ & $\begin{array}{l}\text { Library management remind to the staff } \\
\text { more attention for safety, convenient, } \\
\text { courteous, and continue to find out the }\end{array}$ \\
\hline
\end{tabular}




\begin{tabular}{|c|c|c|}
\hline & visitor's questions & answer what visitor's questions. \\
\hline 6 & $\begin{array}{l}\text { P9- When the library promises to do something by a } \\
\text { certain time, it does so } \\
\text { P23- Employees give personal attention to visitors }\end{array}$ & $\begin{array}{l}\text { The Library staffs seek todo the promises } \\
\text { in certain time and improve the intention } \\
\text { as personal. }\end{array}$ \\
\hline 5 & $\begin{array}{l}\text { P1- Library has modern-looking equipment } \\
\text { P2- The physical facilities are visually appealing and } \\
\text { convenience } \\
\text { P4- Materials associated with the service are visually } \\
\text { appealing }\end{array}$ & $\begin{array}{l}\text { These variables has already good service } \\
\text { quality, based on t-test analysis }\end{array}$ \\
\hline 4 & $\begin{array}{l}\text { P5- Library equippedwith acomputerized data } \\
\text { basesystem } \\
\text { P6- Library equipped with airconditiong system } \\
\text { P7- Pleasant reading room }\end{array}$ & $\begin{array}{l}\text { These variables has already good service } \\
\text { quality, based on t-test analysis }\end{array}$ \\
\hline 3 & $\begin{array}{l}\text { P15- Employees give prompt service to visitors } \\
\text { P22- Library gives individual attention to the visitor } \\
\text { P24- Library understands specifics needs of its } \\
\quad \text { visitors } \\
\text { P25- Library has visitor's interest at heart } \\
\text { P26- Operating hours are convenient to all visitors }\end{array}$ & $\begin{array}{l}\text { The staffs as soon as possible to serve } \\
\text { the visitors, always give attention to } \\
\text { visitors individually, seek to understand } \\
\text { the specific need of the visitors, always } \\
\text { try to serve with heart, and open the } \\
\text { library in accordance with the schedule }\end{array}$ \\
\hline 2 & $\begin{array}{l}\text { P16- Employees are willing to help visitors } \\
\text { P17- Employees are never too busy to respond to } \\
\text { visitor's requests } \\
\text { P18- The employees } 19 \text { instill confidence in visitors }\end{array}$ & $\begin{array}{l}\text { The management always remind to the } \\
\text { employee to make effort in helping the } \\
\text { visitors, never to say busy in respond to } \\
\text { visitor request, and always seek to instill } \\
\text { confidence to visitors. }\end{array}$ \\
\hline 1 & $\begin{array}{l}\text { P10-When a visitor has a problem, the library shows } \\
\text { a sincere interest in solving it } \\
\text { P11- The library performs the service right the first } \\
\text { time } \\
\text { P12- Services are provided at the time the library } \\
\text { promises to do } \\
\text { P13- The records are error-free } \\
\text { P14- Employees tell visitors when services will be } \\
\text { performed }\end{array}$ & $\begin{array}{l}\text { The library staff always to shows a } \\
\text { sincere interest in solving the visitor's } \\
\text { problem, to give the better service at the } \\
\text { first time, always to give the service that } \\
\text { has been promises, never make the error } \\
\text { in serving and always to tell that the } \\
\text { servoces wiil be performed. }\end{array}$ \\
\hline
\end{tabular}

Variables in factor- 8 , factor-5 and factor- 4 are variables that already good quality based on the opinion of the visitors, which these varibles are variable in tangibles component of SERVQUAL. So that, the strategy toward an international college quality is to maintain the facilities that has been owned by CUI. And then to improve the attitudes, capabilities, competences, and skills of the library staff for improvement in serving the visitors. By supporting the best quality of service on library, CUI will become an international college quality.

\section{CONCLUSION AND SUGGESTIONS}

From theresults ofthis study canbe concludedas follows: 
1. Tangibles variables of service quality in library has already better than expected value.

2. The service quality of Reliable, Responsiveness, assurance and empathy variables are still below than expected value.

As suggestions can be delivered that management of library shall execute the improvement of Reliable, Responsiveness, assurance and empathy variables.

\section{REFERENCES}

Abadi Dwi Saputra, 2010, Analysis of Train Passenger Responses on Provided Service Case study: PT. Kereta Api Indonesia and Statens Järnvägar (SJ) AB,Sweden, Thesis, Service ScienceProgramKarlstad UniversitySpring 2010

Ariful Miftakhuddin (2012), Relations Student perception of Quality and use of the library services library by Class XI and XII area of power Expertise power Plant Engineering SMKN 2 Yogyakarta, Skripsi, Prodi Pendidikan Teknik Elektro, Fakultas Teknik Universitas Negeri Yogyakarta

Hair, Joseph F.JR, Anderson RolphE,Tatham Ronald L, Black William , 1995, Multivariate Data Analysis With Reading, Prentice Hall, International Edition, New Jersey

Ibrahim Danjuma, and Amran Rasli (2012), Qualitative Inquiry On Service Quality Of Academic Library In A Nigerian Technological University, Australian Journal of Basic and Applied Sciences, 6(9): 58-65, 2012, ISSN 1991-8178

Jan Hendrik Peters, 1999,Service Management, managing the image ,Trisakti University, Jakarta

Johnson Richard A, Wichern Dean W, 1992, Applied Multivariate Statistical Analysis, Prentice Hall, New Jersey

Julia C. Blixrud (1999), Evaluating Library Service Quality: Use of LibQUAL+, Association of Research Libraries (ARL) in collaboration with the Texas A\&M University Libraries (TAMU)

Khan Rubayet RAHAMAN And Md. Arifur RAHAMAN, 2009, ServiceQualityAttributesAffectingTheSatisfactionofRailwayPassengersofSelectiveRo uteinSouthwestern Part of Bangladesh, Theoretical and Emperical Researches in Urban Management, Number 3 (12)/ August 2009

Narit Nimsomboon and Haruki Nagata (2003), Assessment of Library Service Quality 
At Thammasat University Library System, Research Center for Knowledge CommunitiesUniversity of Library and Information Science, JAPAN

Nurosis, Marija J.,1993, SPSS for Windows Professionals Statistic Release 6.0, Chicago , SPSS Inc.

Panday, Rorim (2014), Service Quality Analysis of Argo Parahyangan Train as a tool for improving the service, paper at 11th INSYMA, UBAYA, Batu, Malang

Shafiq Ur Rehman (2012), Measuring service quality in public and private sector university libraries of Pakistan, Pakistan Journal of Library \& Information Science, ISSN 16804465

Sheeba. A. A and Dr. K. Kumuthadevi, 2013, Service Quality of South Indian RailwayDeterminants of Passenger Satisfaction in Trains., International Journal of Business and Management InventionISSN (Online): 2319 - 8028, ISSN (Print): 2319 - 801X, www.ijbmi.org Volume 2 Issue $2 \|$ February. 2013\| PP.49-54

Syed Muhammad Irfan, Daisy Mui Hung Kee and Saman Shahbaz, 2012, Service Quality and Rail Transport in Pakistan: A Passenger Perspective, World Applied Sciences Journal 18 (3): 361-369, 2012, ISSN 1818-4952, (C) IDOSI Publications, 2012, DOI: 10.5829/idosi.wasj.2012.18.03.3044

Siti Musthofainah (2009), Student Perception on Facilities of The Library of Public State Vacational School 1 Bantul Yogyakarta, skripsi ilmu perpustakaan pada Prodi ilmu Perpustakaan, UIN sunan Kalijaga, yogyakarta.

Sunani (2012), Kualitas Pelayanan Perpustakaan Politeknik Negeri Sriwijaya terhadap kepuasaan Mahasiswa, Jurnal ILMIAH Volume V No.1, 2012

Vera Patrício, Rogério Puga Leal, Zulema Lopes Pereira (2006), Applicability of SERVQUALin restaurants: an exploratory study in a Portuguese resort, Faculty of Science and Technology, Universidade Nova de Lisboa, Portugal 